\title{
The Relationship between Spiritual Intelligence and Organizational Development of Teachers in Education Department
}

\author{
Saeid Chegeni \\ Senior expert of General Psychology \\ Email:saeid.chegeni@yahoo.com
}

Javad Karimi

State University of Malayer

Doi:10.5901/mjss.2016.v7n4s1p274

\begin{abstract}
Organizational development of employees in organizations such as education department is a factor for the further growth of spiritual intelligence in teachers. This study was conducted to determine the relationship between spiritual intelligence and organizational development among teachers in the education area in the city of Boroujerd. This study is descriptive and correlational. The research population are 635 teachers. The sample size was determined based on the sample of 245 subjects who were selected by using stratified random sampling. Data collection tools are including standard questionnaires of spiritual intelligence and organizational development that validity and reliability of both tools were approved. Obtained data was investigated by using simple and multivariate regression analysis by using SPSS software. Findings showed that there is a significant relationship between spiritual intelligence and organizational development and its components, and then believe in a comprehensive approach, the ability to cope and deal with problems, moral individualities, self-awareness, love and kindness, and organizational development. By findings of this study it can be concluded that efforts to increase teachers' moral intelligence improves the work efficiency and enhance the quality of teaching and create effective communication with the students.
\end{abstract}

Keywords: spiritual intelligence, organizational development, education

\section{Introduction}

The era that we are living in is an age of complexity and change, organizations in such an era are like the players, which walk on a thin thread. We are always concerned with people who do Acrobatics and wonder about their actions, but we need to realize that the survival of organizations today should be more considered. Perhaps it is for this reason that we are faced with new ways in the field of management to get rid of this risk. For example, the emergence of concepts such as learning organizations, agencies graphics Hulu, time management, productivity management, total quality management, management by objectives, quality of working life, entrepreneurial organizations are some kind of these concerns. One of the topics that scientists and psychologists are interested in, is spiritual intelligence. Spiritual intelligence is discussed not only in the individual but also in organizational areas of interest. In addition to the psychological field into other areas of the humanities, it includes management. It is safe to say that perhaps it causes to increase research in the field of spirituality and has dramatic impact on improving individual and organizational performance. In fact, in this age of modernity, gods speed up and many organizations Hobson almost constantly renew them .It seems that new and deeper intelligence and leadership is required to help managers for better management and lead to more effective manner. Some people might say that nothing is new in the history of the development of management and leadership learning. Despite this attention it means rarely found in the literature (George, 2006). AMRAAM defines spiritual intelligence: Defines spiritual intelligence, spiritual intelligence and ability to take advantage of resources, values and spiritual qualities in such a way that to enhance daily functioning and well-being (physical and mental) (2009, Amram). The general education as a pillar of sustainable development is recognized every nation in the world, a large proportion of their national income to expand, improve efficiency allocates (Seif, 2006). Department of Education, the organization that has its manpower, but if people behave properly guided to organizational goals, talents and skills at the service of the organization will be more to do. The role of primary teachers is more prominent than the other members of the organization; for elementary teachers play a vital role in the formation, evolution, behavior, 
attitudes, skills and information students are required throughout life. (Seif, 2006). Organizational scholars have concluded that only managing and directing the organization is not enough. But if people behave properly in order to lead organizational goals, your goals will surely organization. Key of the organization survival is the constant improvement and innovation in variable and turbulent environments. Accordingly, theories, approaches and different tools for development and organizational change was proposed, but the implementation of each of these approaches have not been effective (Faghihi and Rajab beigy, 192: 2007). King's (2007) research was done on spiritual intelligence at the University of Canada

He is the spiritual intelligence of a set of adaptive mental capacities that are based on the aspects of spiritual and transcendent reality. Especially those that relate to the nature of being a personal meaning, transcendence and alert modes are soaring. Edward (2003) has raised the issue of the distinction between being smart and being aware spiritually significant deal of knowledge about spiritual intelligence. This distinction reflects the distinction between scientific knowledge and theoretical basis. lang Puyit Luis Vela (2014), in his study entitled Ethical Leadership in Canadian schools, organizations, facilities tensions related to ethical leadership showed that ethic, has strong effect in support of their cultures and language identity of the French language, and that is the survival levels. Zonk and Shakur (2013) "in the study of moral education in class" showed that the teacher's role is essential in the implementation of programs that are related to the development of moral education in the students for their professional development.

So it's different to know very much about spiritual traditions expression of spiritual intelligence through the use of personal prayer and meditation to solve a moral issue.

In this study, it is tried to evaluate the spiritual intelligence and its components on organizational development of teachers.

\section{Method}

The study population now is all the administrators and teachers in the school in 2016 the first area of the city of Boroujerd. Their number is estimated to 635 people and samples size was determined based on the sample of 245 subjects who were selected by using stratified random sampling. In this study, the subjects is used to stratify random sampling method.

The questionnaire used in this study included two questionnaires of spiritual intelligence and agency employees.

Spiritual Intelligence Questionnaire:

The questionnaire used in this study in order to measure spiritual intelligence, in four main groups: Holistic and faithfulness, ability to cope and deal with problems, addressing moral individualities, self-awareness and love and interest (Wind, 2010).

\section{1 organizational development questionnaire:}

This questionnaire was developed by the Likert method designed to mix two questions. Its components are transparent openness of the system with test material 7,6,5,3,2,1, trust each other with feedback from internal and external substance,; 11,10,9,8 tests with test material 15,14,13,12; 19,18,17,16 collaborate with the test substance; foster authority with the data structure of the test material with the test material layer 4 is low twenties.

In the questionnaire, Measure 5 options (Likert) strongly disagree to strongly agree was used when the option is listed in the budget. For options strongly disagree, disagree, no opinion, I agree I completely agree respectively 1-2-3-4-5 score is considered. Validity of the questionnaire was presented to the owner of expert teachers with the comments of the final acts accordingly. To determine the reliability of the questionnaire was distributed randomly among 30 people from the community through the alphabet alpha reliability coefficient of $92 /$. These following findings were obtained:

\section{Findings}

These assumptions were used in the analysis of Pearson correlation and, Pearson correlation test. Results in Table 1 were presented. Table 1 shows the significant relationship between spiritual intelligence and organizational development education teachers $(001 / . \mathrm{R}=362$ I., $\mathrm{P}<)$. 
Table 1: Description of gender sample

\begin{tabular}{|c|c|c|}
\hline The percentage of frequency & frequency & gender \\
\hline 69 & 169 & women \\
\hline 31 & 76 & men \\
\hline 100 & 245 & whole \\
\hline
\end{tabular}

Table 2: Statistical parameters of spiritual intelligence of organizational development variables and its components

\begin{tabular}{|c|c|c|c|c|c|c|}
\hline $\begin{array}{c}\text { Variable } \\
\text { Aounting rack }\end{array}$ & $\begin{array}{c}\text { Organizational } \\
\text { development }\end{array}$ & $\begin{array}{c}\text { Spiritual } \\
\text { Intelligence }\end{array}$ & $\begin{array}{c}\text { Holistic and } \\
\text { faithfulness }\end{array}$ & $\begin{array}{c}\text { Ability to cope and } \\
\text { deal with problems }\end{array}$ & $\begin{array}{c}\text { Moral } \\
\text { individualities }\end{array}$ & $\begin{array}{c}\text { Self-awareness, } \\
\text { love, affection }\end{array}$ \\
\hline Sample & 245 & 245 & 245 & 245 & 245 & 245 \\
\hline The mean & & $4 / 014$ & $3 / 61$ & $3 / 69$ & $3 / 60$ & $3 / 47$ \\
\hline Standard deviation & & $0 / 399$ & $0 / 348$ & $0 / 317$ & $0 / 331$ & $0 / 327$ \\
\hline The smallest score & & 3 & $2 / 75$ & 3 & $2 / 62$ & $2 / 57$ \\
\hline The biggest score & & $4 / 7$ & $4 / 33$ & $4 / 36$ & $4 / 38$ & $4 / 43$ \\
\hline variation range & & $1 / 7$ & $1 / 58$ & $1 / 36$ & $1 / 75$ & $1 / 86$ \\
\hline
\end{tabular}

\section{The Hypothesis}

There is a significant relationship between spiritual intelligence and organizational development of education teachers.

Table 3: Results of regression analysis for hypothesis

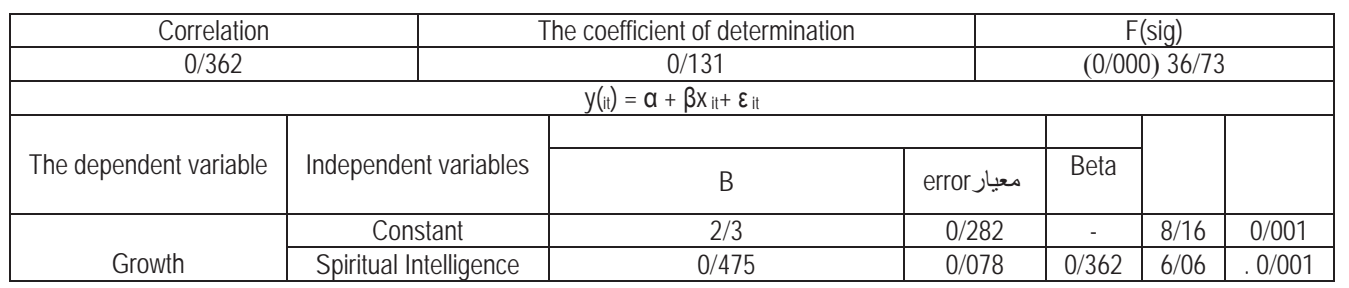

The results of simple regression analysis (Table 4-6) shows there that is a significant relationship between spiritual intelligence and organizational development of education teachers $(001 / 0, \mathrm{P}<362 / 0=\mathrm{R})$. Therefore, we assume that $\mathrm{H} 0$ is rejected and $\mathrm{H} 1$ accepted. The coefficient of determination indicates that only 13 percent of the variance in organizational development moral intelligence can be explained by teachers $(13 / 0=\mathrm{R} 2)$. The $\mathrm{F}$ test indicates that there is a linear relationship between two variables that use regression analysis confirms. The significance level (sig) $t$ test for less than 5 percent is variable in moral intelligence. Therefore, we can say that spiritual intelligence had a significant effect on organizational development so that the direct effect is that when there is more moral intelligence so there is more organizational development. The beta also shows that the size of a standard deviation of the Spiritual Intelligence, $362 / 0$ and Changes in organizational development variable will be created.

\section{Discussion and Conclusion}

This section reviews the results and findings of this study and compares them with similar studies that are described above.

According to the results obtained in relation to the basic hypotheses, test results assumption (hypothesis I) showed there is a significant relationship between spiritual intelligence and organizational development of education teachers $(001 / 0, \mathrm{P}<362 / 0=\mathrm{R})$. The main research hypothesis was confirmed.

These findings are consistent with Abbas Oghli (2014), Akbari et.as (2013), Tomaso et. Al (2006), Jarmilo et. Al (2006) researches. About this finding we can say that increasing the spiritual intelligence of teachers, cause to increase their process of working and also better teaching performance and creating better relationship with students. If we create intelligence with proper capacity for new situation, then manner, will cover the capacity of this organization. For explaining this finding we can say, if the reliance, respect and loyalty are low, so the workers' sprit is become low, and 
lead to decrease the organization benefits. For this purpose, paying attention to the elements of manner in the organization can help the organization to keep its manner in the complicated situation, and if bosses and teachers have forgiveness in their work, if they do something wrong, it is easy for them to confess, and examine their errors, and use them for reaching better promotions, and if another person have a mistake in their situation, they are be able to forgive them and try to report some behavioral manners which may happen in their work, and if someone do something wrong, because of forgiveness of the bosses, they can believe their employees. So controlling the behavior in organizations, has an effect on its classification, and the commitment of the employees. Paying attention to all the people and member of sub groups, will increase the benefits of organizations. Because it creates the human power, reliance of people and also decrease the amount of fines.

\section{References}

Persian sources

Arasteh, Hamid Reza \& Jahed, Hossein Ali (2012). Ethics in higher education Universities and options to improve. Nasha ol elm, 2, 4031

Ebrahim Zadeh, Mohammad Taghi (2006). Angyz-hhayajtmay and self-esteem. Isfahan: Press Hur, S45-55.

Ibrahim Shahin (2012). The relationship between emotional intelligence and spiritual intelligence in students' life satisfaction witted high school girls in Birjand. Master's thesis, Islamic Azad University Qaenat.

Ismail Yazxari , Zahra . et al. (2013). Moral intelligence relationship with the administrators restore confidence. .manner In Science and Technology, 1, $85-97$

Akbari, Hossein. (2001). Introduction to management and self-esteem. Tehran: Office of Cultural Research, Volume I, Second Edition, p. 21.

Akbari, Abbas and Hussein-Zadeh, Davoud. (2013). Relationship between knowledge management and organizational learning from the perspective of Saveh city high school teacher. MA thesis, University of Saveh

Bahrami, Mohammad Amin et al. (2012). The level of moral intelligence faculty and staff members of Yazd University of Medical Sciences. Ethics and History of Medicine, 6, 96 and 75.

Parsa, Mohammad. (2005). the new field of psychology. Tehran: mission.

Pierce et al. (1993). Adult supervision management principles and strategies for organizational development, translation Mlrzaee. Gorgan: Dynamic message, Third Edition, p. 6.

Tarkhān, Mohammad. (1998). Management and development organization, First Printing Tehran: Next.

Hassan Khoei, Seema (2007). To investigate the relationship between emotional intelligence and job satisfaction of managers Tehran inhibit job: contemporary culture.

Hassan Khoei, Sima. (2007). the relationship between emotional intelligence and defense mechanisms. MA thesis, Faculty of Education, Tehran University.

KHADIVI, Asad allah. (2008). an introduction to organizational behavior in organizations of the third millennium. Tabriz worthy. MA thesis, University of Tabriz Islamic Azad.

Zakeri, Ali Akbar. (2009). morally responsible. Tehran: Ascension.

Saki, Reza. (2010). School learning-centered leadership. Tehran: education. Site: http://www.yjc.ir

Salamati, Abbas. (1996). the relationship between intelligence and moral transformation in the junior boys city of Arak. Master's thesis, University of Tabriz Islamic Azad.

Saif Ali Akbar (2006). Educational psychology (Psychology of Learning and Teaching). Tehran: Cognizant.

Shermerhorn, Jan.Ar (2008). Organizational Behavior Management translator Mehdi Iran-Nejad et al. Tehran: Administrators.

Shoari Nezhad, Ali Akbar. (2010). Development and organizational policies. Tehran: Rahdan, S24-25

Shafee Abdullah (2008). Vocational guidance and career counseling and career choice theories. Tehran: Growth

Tousi, Mohammad. (2002). Self-esteem and self-esteem and the factors affecting it, Tehran: Knowledge, Volume 11, p. 12.

Abbasi Oghli, Gholi (2013). Bank Melli Iran executives predicted on the basis of moral intelligence chief Nha. Islamic Azad University Branch.

Kampn Hood, Al, kiwi,. (2009). Research Methodology in Social Sciences, translator Abdul Nick Gohar.

Couper Smith (1967). Principles of supervision and management and increase development in the organization, Rasht: Gil inscription, first edition, p. 3.

Kediyar, Parvin. (2009). Moral psychology. Tehran: Cognizant.

Ganji, Mirza Taqi (2000). The organization and employees' organizations and increase self-esteem, Chapsvm. Tehran: Senior.

Lotfabadi, Hossein. (2006). Review theories of moral development by Piaget, Kohlberg, and Bandura and provide a new model for research on moral development of students. Educational Innovations, 11, 105-76

Link, D total, F. (2004). Moral Intelligence, translated by Ali Mohammad Goudarzi. Tehran: expressive.

Mahmoudi, Gholamreza. (2013). Moral intelligence and its role in different aspects of life.

Mokhtaripoor, Marzieh and Siadat, Ali. (2009). the relationship between moral intelligence with team leadership in managers from the viewpoint of faculty members of University of Medical Sciences. Health Management, 36, 61-6

Mokhtaripoor, Marzieh and Siadat, Ali. (2010). Abadhvsh Comparative Study of Ethics and scientists on the Quran and Islamism. Islamic 
Studies and Psychology, 4, 118-97

Beheshtifar, M. \&Esmaili, Z.(2011). Effect of moral intelligence onleadershipEconomics Finance and Administrative. 43, 1-17Bengston, M. \& Ohlsson, B. (2010). The nursing andmedical students motivation to Attainknowledge. Nurse Educ Today. 30, 150-166 Clarken, R.H. (2003).Moral intelligence in the Schools. Available at: http://sccn612final.wikispaces.com

Coles, R. (2007). The moral intelligence of children:How to raise a moral Child. New York: NAL/Dutto

Craft, John M and Matteson, Michael T (1994). Organizational Behavior and Management. Published .By: Mc Graw. Hill Irwin. Langlois,L\& Lapointe,C. (2014). Ethical leadership in Canadian school organizations. Educ Manag Admin Leadership. 35, 47-60. Lau, H.C. \& Idris, M.A. (2005). Soft foundations of thecritical success factors on TQM implementation in Malaysia. TQM Magaz. 13, 5 Lennick, D\& Kiel, F. (2008). Moral Intelligence: Enhancing Business Performance \& Leadership Success. Pensylvania: Wharton School. Lennick, D\& Kiel, F. (2011). Moral intelligence: enhancing business performance and leadership success in turbulent times. New York: PrenticeHal.

Lennick, D\& Kiel, F. (2012). A work sheet for defining your code of ethics. Available from: http://troop351madison.org / MorallQ.pdf. Lordanoglou, D. (2008). The teacher as Leader: the relationshipeffectiveness, emotional Luthans, Fred (1989). Organizational Behavior. Mc Graw- Hill In ternational Editions Mart, Gary (2001) Management "leading people and organizations in the 21ST century" . prentice Hall. Martin, d.e\& Sloan I.r. (2008). Plagiarism, integrity, and workplace deviance: a criterion study. Ethics and Behavio. 19,36-51. Manallack, S. (2011), Is honesty the best form of business risk management?, Available at http://www.domain-b.com.

Prati, C.M\& Douglas, C\& Ferris G.R.(2003). The role of emotional intelligence on team leadership.Organizational Analysis. 11, 363-389. Zdenek, B. and Schochor, D. (2013), Developing moral literacy in classroom, Journal of Educational Administration, 45(4): 514-32. 